\title{
PENGARUH LIKUIDITAS DAN PROFITABILITAS TERHADAP NILAI PERUSAHAAN PADA PERUSAHAAN SUB SEKTOR KONSTRUKSI DAN BANGUNAN YANG TERDAFTAR DI BURSA EFEK INDONESIA
}

\author{
Oleh : \\ Rismawaty Pardede \\ S1 Akuntansi \\ Liper Siregar, Parman Tarigan, Supitriyani
}

Abstrak

Tujuan dari penelitian ini adalah untuk mengetahui gambaran likuiditas, profitabilitas, dan nilai perusahaan serta pengaruh likuiditas dan profitabilitas terhadap nilai perusahaan pada Perusahaan Sub Sektor Konstruksi dan Bangunan yang Terdaftar di Bursa Efek Indonesia. Desain penelitian yang digunakan adalah penelitian kepustakaan dengan teknik analisis data berupa: uji asumsi klasik, analisis deskriptif kualitatif dan kuantitatif.

Hasil persamaan regresi adalah $\hat{Y}=8,871-4,778 X_{1}+13,343 X_{2}$. Koefisien korelasi $(r)$ sebesar 0,654 dan nilai $R$ sebesar $42,7 \%$. Hasil uji $F$ menunjukkan $F_{\text {hitung }}>F_{\text {tabel }}(11,947>3,29)$ atau tingkat signifikansi $0,000<0,05$ berarti likuiditas dan profitabilitas berpengaruh signifikan terhadap nilai perusahaan pada Perusahaan Sub Sektor Konstruksi dan Bangunan yang Terdaftar di Bursa Efek Indonesia. Hasil uji $t$ untuk likuiditas $t_{\text {hitung }}<t_{\text {tabel }}(4,417>2,03693)$ atau Sig. $<$ alpha $(0,000<0,05)$, berarti likuiditas berpengaruh signifikan terhadap nilai perusahaan pada Perusahaan Sub Sektor Konstruksi dan Bangunan yang terdaftar di Bursa Efek Indonesia. Hasil uji $t$ untuk profitabilitas $t_{\text {hitung }}>t_{\text {tabel }}$ $(3,451>2,03693)$ atau Sig.<alpha $(0,002<0,05)$, berarti profitabilitas berpengaruh signifikan terhadap nilai perusahaan pada Perusahaan Sub Sektor Konstruksi dan Bangunan yang terdaftar di Bursa Efek Indonesia.

Saran yang dapat diberikan adalah perusahaan sebaiknya memperhatikan likuiditas dan profitabilitas sebagai salah satu jalan untuk meningkatkan nilai perusahaan. Kata Kunci: Likuiditas, Profitabilitas, dan Nilai Perusahaan.

\section{Abstract}

The purpose of this research is to know the description of liquidity, profitbility and firm's values and the effect of liquidity and profitability of firm's value at Company Sub Sector Building and Contruction listed on the Indonesia Stock Exchange. The research design in this research is a library research and technique analysis in this research as: assumption classic test, qualitative and quantitative descriptive analysis

The regression is $\hat{Y}=8,871-4,778 X_{1}+13,343 X_{2}$. Correlation coefficient of $r=0,654$ and $R$ Square of $42,7 \%$. Simultaneous test results is $F_{\text {count }}>F_{\text {table }}(11,947>3,29)$ or significance level $0,000<0,05$ means liquidity and profitability has significant effect on firm's value at Company Sub Sector Building and Contruction listed on the Indonesian Stock Exchange. The t-test results show liquidity has $t_{\text {count }}<t_{\text {table }}$ or $4,471>2,03693$ or significance level $0,000<0,05$, means liquidity has significant effect on firm's value at Company Sub Sector Building and Contruction listed on the Indonesian Stock Exchange. The $t$-test results that profitability to $t_{\text {count }}>t_{\text {table }}(3,451>2,03693)$ or significance level $0,00<0,05$, profitability has significant effect on firm's value at Company Sub Sector Building listed on the Indonesian Stock Exchange.

The result of this research suggests that company should improve managment should pay more attention to liquidity and profitability as a way to enhance shareholder value in addittion.

Keywords: Liquidity, Profitability, and Firm's Value

\section{A. PENDAHULUAN}

\section{Latar Belakang Masalah}

Nilai perusahaan mencerminkan kinerja perusahaan yang dapat mempengaruhi persepsi investor terhadap perusahaan. Nilai perusahaan yang semakin tinggi merupakan keinginan setiap pemilik perusahaan karena nilai yang tinggi menunjukkan besarnya kemakmuran para pemegang saham yang merupakan tujuan utama perusahaan. Salah satu cara untuk menghitung nilai perusahaan adalah dengan menggunakan Market To Book Ratio (MBR).
Tabel 1

Gambaran MBR Perusahaan Sub Sektor Konstruksi dan Bangunan Periode 2012-2016

\begin{tabular}{|c|c|c|c|c|c|c|c|}
\hline \multirow{2}{*}{ No } & \multirow{2}{*}{ Emiten } & $\begin{array}{c}\mathbf{2 0 1 2} \\
\text { (kali) }\end{array}$ & $\begin{array}{c}\mathbf{2 0 1 3} \\
\text { (kali) }\end{array}$ & $\begin{array}{c}\mathbf{2 0 1 4} \\
\text { (kali) }\end{array}$ & $\begin{array}{c}\mathbf{2 0 1 5} \\
\text { (kali) }\end{array}$ & $\begin{array}{c}\mathbf{2 0 1 6} \\
\text { (kali) }\end{array}$ & $\begin{array}{c}\text { Rata-rata } \\
\text { (kali) }\end{array}$ \\
\hline 1 & ADHI & 2,290 & 1,499 & 3,049 & 1,479 & 1,363 & $\mathbf{1 , 9 3 6}$ \\
\hline 2 & DGIK & 0,791 & 0,784 & 0,899 & 0,435 & 0,402 & $\mathbf{0 , 6 6 2}$ \\
\hline 3 & PTPP & 2,427 & 2,832 & 7,246 & 4,282 & 1,883 & $\mathbf{3}, 734$ \\
\hline 4 & SSIA & 3,176 & 1,136 & 1,901 & 1,157 & 0,701 & $\mathbf{1 , 6 1 4}$ \\
\hline 5 & TOTL & 4,658 & 2,264 & 4,789 & 2,471 & 2,819 & $\mathbf{3 , 4 0 0}$ \\
\hline 6 & WIKA & 3,511 & 3,290 & 5,672 & 3,710 & 1,278 & $\mathbf{3 , 4 9 2}$ \\
\hline 7 & WSKT & 2,048 & 1,086 & 4,903 & 2,374 & 3,127 & $\mathbf{2 , 7 0 8}$ \\
\hline
\end{tabular}


\begin{tabular}{|l|l|l|l|l|l|l|} 
Rata-rata Akhir & 2,700 & 1,841 & 4,066 & 2,273 & 1,654 & 2,507 \\
\hline
\end{tabular} Sumber: www.idx.co.id, data diolah

Dari Tabel 1 menunjukkan MBR Perusahaan Sub Sektor Konstruksi dan Bangunan mengalami fluktuasi dan cenderung menurun. Nilai rata-rata MBR adalah 2,507. Nilai masing-masing MBR menunjukkan kemampuan perusahaan dalam meningkatkan nilai perusahaannya di setiap periodenya.

\section{Rumusan Masalah}

a. Bagaimana gambaran likuiditas, profitabilitas, dan nilai perusahaan pada Perusahaan Sub Sektor Konstruksi dan Bangunan yang Terdaftar di Bursa Efek Indonesia.

b. Bagaimana pengaruh likuiditas dan profitabilitas terhadap nilai perusahaan pada Perusahaan Sub Sektor Konstruksi dan Bangunan yang Terdaftar di Bursa Efek Indonesia baik secara simultan maupun parsial.

\section{Tujuan Penelitian}

a. Untuk mengetahui gambaran likuiditas, profitabilitas, dan nilai perusahaan pada pada Perusahaan Sub Sektor Konstruksi dan Bangunan yang Terdaftar di Bursa Efek Indonesia.

b. Untuk mengetahui pengaruh likuiditas dan profitabilitas terhadap nilai perusahaan pada Perusahaan Sub Sektor Konstruksi dan Bangunan yang Terdaftar di Bursa Efek Indonesia baik secara simultan maupun parsial.

\section{Metodologi Penelitian}

Penelitian ini menggunakan data sekunder dengan cara mengakses www.idx.co.id. Desain penelitian dalam penelitian ini adalah penelitian kepustakaan (library research) dengan teknik analisis data adalah Uji Asumsi Klasik, Analisa Deskriptif Kualitatif, Analisa Deskriptif Kuantitatif.

\section{B. LANDASAN TEORI}

\section{Laporan Keuangan}

Menurut Munawir (2004:2), laporan keuangan pada dasarnya adalah hasil proses akuntansi yang dapat digunakan sebagai alat berkomunikasi antara data keuangan atau aktivitas suatu perusahaan dengan pihak-pihak yang berkepentingan dengan data aktivitas perusahaan tersebut.

Menurut Harahap (2011:205), laporan keuangan adalah output dan hasil akhir dari proses akuntansi.

\section{Analisis Rasio Keuangan}

Menurut Kasmir (2010:93), rasio keuangan merupakan kegiatan yang ada dalam laporan keuangan yang membandingkan angka-angka dengan cara membagi satu angka dengan angka lainnya. Perbandingan dapat dilakukan antar komponen yang ada di antara laporan keuangan atau antara satu komponen dengan komponen dalam satu laporan keuangan.

Menurut Munawir (2004:64), rasio keuangan adalah menggambarkan suatu hubungan atau perimbangan antara suatu jumlah tertentu dengan jumlah yang lainnya.

\section{Likuiditas}

Menurut Kasmir (2010:110) bahwa rasio likuiditas (liquidity ratio) merupakan rasio yang menggambarkan kemampuan perusahaan memenuhi hutang jangka pendek.

Menurut Kasmir (2010:114) faktor-faktor yang mempengaruhi likuiditas tersebut antara lain:

1) Ketidaktersediaan dana yang dimiliki oleh perusahaan untuk menutupi hutanghutang yang segera jatuh tempo.

2) Perusahaan tidak memiliki dana yang cukup untuk melunasi hutang hutangnya.

3) Kelalaian manajemen perusahaan dalam menjalankan usahanya dan mengevaluasi kinerja keuangan perusahaan.

4) Pihak manajemen perusahaan tidak menghitung rasio keuangan yang diberikan yang diberikan sehingga tidak mengetahui kondisi perusahaan yang sudah tidak mampu lagi karena nilai hutangnya lebih tinggi dari aset lancarnya.

\section{Profitabilitas}

Menurut Astuti (2004:36), rasio profitabilitas adalah rasio yang mengukur kemampuan perusahaan menghasilkan laba. Rasio profitabilitas memberikan ukuran tingkat efektivitas manajemen suatu perusahaan hal ini ditunjukkan oleh laba yang dihasilkan dari penjualan dan pendapatan investasi.

Menurut Brigham dan Joel (2012:146), faktor yang mempengaruhi profitabilitas adalah

1) Rasio Likuiditas

2) Rasio Manajemen Aset

3) Rasio Manajemen Hutang.

\section{Nilai Perusahaan}

Menurut Keown et.al. (2004:470), nilai perusahaan adalah nilai pasar atas surat berharga hutang dan ekuitas perusahaan yang beredar.

Menurut Horne dan John (2012:3), faktorfaktor yang mempengaruhi nilai perusahaan adalah:

a. Keputusan Investasi

b. Keputusan Pendanaan

c. Keputusan Manajemen Aset

\section{Pengaruh Likuiditas dan Profitabilitas} terhadap Nilai Perusahaan

Menurut Brigham dan Joel (2010:150), jika rasio likuiditas, manajemen aset, manajemen 
hutang, dan profitabilitas semuanya terlihat baik dan jika kondisi ini berjalan terus-menerus secara stabil maka rasio pasar akan tinggi, harga saham kemungkinan tinggi sesuai dengan yang diperkirakan.

Menurut Kasmir (2010:196), dengan memperoleh laba yang maksimal maka perusahaan dapat berbuat banyak bagi kesejahteraan pemilik, karyawan, serta meningkatkan mutu produk dan melakukan investasi baru. Semakin tinggi rasio profitabilitas yang dihasilkan maka akan menarik minat investor dalam menginvestasikan dananya pada perusahaan tersebut.

\section{PEMBAHASAN}

1. Analisis

a. Analisis Deskripsi Kualitatif

1) Gambaran Likuiditas Perusahaan Konstruksi dan Bangunan

Rata-rata Current Ratio (CR) pada Perusahaan Konstruksi dan Bangunan periode 2012-2016 pada Tabel 2 .

Tabel 2

CR Perusahaan Sub Sektor Konstruksi dan Bangunan Periode 2012-2016

\begin{tabular}{|c|c|c|c|c|c|c|c|}
\hline & & & & 20 & & & \\
\hline \multirow{2}{*}{ N } & \multirow[b]{2}{*}{ Emiten } & \multicolumn{5}{|c|}{ Current Ratio } & \multirow{2}{*}{$\begin{array}{l}\text { Rata- } \\
\text { rata } \\
\text { (kali) }\end{array}$} \\
\hline & & $\begin{array}{l}2012 \\
\text { (kali) }\end{array}$ & $\begin{array}{l}2013 \\
\text { (kali) }\end{array}$ & $\begin{array}{l}2014 \\
\text { (kali) }\end{array}$ & $\begin{array}{l}2015 \\
\text { (kali) }\end{array}$ & $\begin{array}{l}2016 \\
\text { (kali) }\end{array}$ & \\
\hline 1 & $\mathrm{ADHI}$ & 1,244 & 1,391 & 1,342 & 1,560 & 1,291 & 1,366 \\
\hline 2 & DGIK & 1,778 & 1,564 & 1,564 & 1,564 & 1,195 & 1,533 \\
\hline 3 & PTPP & 1,358 & 1,356 & 1,377 & 1,388 & 1,533 & 1,402 \\
\hline 4 & SSIA & 1,725 & 2,006 & 1,680 & 1,562 & 1,783 & 1,751 \\
\hline 5 & TOTL & 1,444 & 1,580 & 1,298 & 1,258 & 1,281 & 1,372 \\
\hline 6 & WIKA & 1,101 & 1,095 & 1,123 & 1,185 & 1,476 & 1,196 \\
\hline 7 & WSKT & 1,472 & 1,434 & 1,362 & 1,323 & 1,172 & 1,353 \\
\hline \multirow{2}{*}{\multicolumn{2}{|c|}{ Rata-rata }} & & & & & & \\
\hline & & 1,446 & 1,489 & 1,405 & 1,406 & 1,390 & 1,425 \\
\hline \multicolumn{7}{|c|}{ Rata-rata Keseluruhan } & 1,425 \\
\hline \multicolumn{7}{|c|}{ Nilai CR Maksimum } & 2,006 \\
\hline \multicolumn{7}{|c|}{ Nilai CR Minimum } & 1,095 \\
\hline
\end{tabular}

Sumber: www.idx.co.id(Data diolah)

Dari Tabel 2, dapat disajikan grafik CR sebagai berikut:

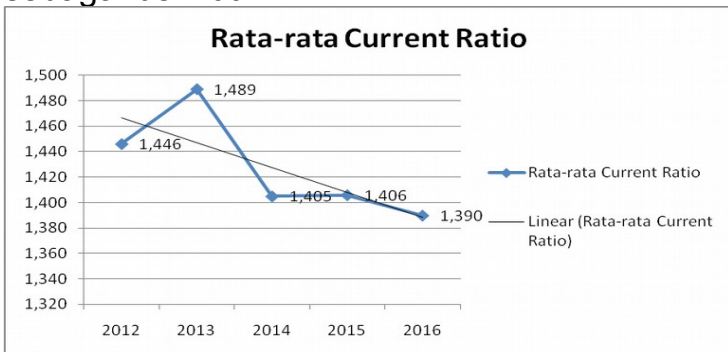

Sumber: Data Diolah (www.idx.co.id)

\section{Gambar 1}

Grafik CR Perusahaan Sub Sektor Konstruksi dan Bangunan periode 2012-2016

Berdasarkan Tabel 2 dan Gambar 1 perkembangan CR Perusahaan Sub Sektor Konstruksi dan Bangunan 2012-2016 berfluktuasi dan cenderung menurun. Nilai rata - rata CR sebesar 1,425. CR maksimum sebesar 2,006 pada tahun 2013 mengindikasikan kurangnya efisiensi dalam penggunaan aset lancar perusahaan sebagai upaya untuk menghasilkan laba yang lebih besar. CR minimum perusahaan sebesar 1,095 berada pada tahun 2013. Rendahnya CR perusahaan disebabkan oleh peningkatan hutang lancar lebih tinggi dibanding dengan peningkatan aktiva lancar.

2) Gambaran Profitabilitas pada Perusahaan Sub Sektor Konstruksi dan Bangunan periode 2012-2016

Rata-rata ROA pada Perusahaan Sub Sektor Konstruksi dan Bangunan sebagai berikut :

Tabel 3

ROA Perusahaan Sub Sektor Konstruksi dan Bangunan periode 2012-2016

\begin{tabular}{|c|c|c|c|c|c|c|c|}
\hline & & & & & & & \\
\hline \multirow[b]{2}{*}{ No } & \multirow[b]{2}{*}{ Emiten } & \multicolumn{5}{|c|}{ Return On Assets } & \multirow{2}{*}{$\begin{array}{l}\text { Rata- } \\
\text { rata } \\
\text { (kali) }\end{array}$} \\
\hline & & $\begin{array}{l}2012 \\
\text { (kali) }\end{array}$ & $\begin{array}{l}2013 \\
\text { (kali) }\end{array}$ & $\begin{array}{l}2014 \\
\text { (kali) }\end{array}$ & $\begin{array}{l}2015 \\
\text { (kali) }\end{array}$ & $\begin{array}{r}2016 \\
\text { (kali) }\end{array}$ & \\
\hline 1 & $\mathrm{ADHI}$ & 0,027 & 0,042 & 0,031 & 0,028 & 0,016 & 0,023 \\
\hline 2 & DGIK & 0,027 & 0,031 & 0,030 & 0,002 & $-0,249$ & $-0,032$ \\
\hline 3 & PTPP & 0,036 & 0,034 & 0,036 & 0,044 & 0,037 & 0,038 \\
\hline 4 & SSIA & 0,152 & 0,128 & 0,086 & 0,059 & 0,014 & 0,088 \\
\hline 5 & TOTL & 0,088 & 0,096 & 0,066 & 0,067 & 0,075 & 0,078 \\
\hline 6 & WIKA & 0,046 & 0,050 & 0,047 & 0,036 & 0,037 & 0,043 \\
\hline 7 & $\begin{array}{c}\text { WSK } \\
T\end{array}$ & 0,030 & 0,042 & 0,040 & 0,035 & 0,030 & 0,035 \\
\hline \multicolumn{2}{|c|}{$\begin{array}{c}\text { Rata-rata } \\
\text { Akhir }\end{array}$} & 0,058 & 0,060 & 0,048 & 0,039 & $-0,006$ & 0,039 \\
\hline \multicolumn{7}{|c|}{ Rata-rata Keseluruhan } & 0,039 \\
\hline \multicolumn{7}{|c|}{ Nilai ROA Maksimum } & 0,152 \\
\hline \multicolumn{7}{|c|}{ Nilai ROA Minimum } & $-0,249$ \\
\hline
\end{tabular}

Sumber: www.idx.co.id (Data diolah)

Berdasarkan Tabel 3 disajikan grafik ROA Perusahaan Sub Sektor Konstruksi dan Bangunan periode 2012-2016 sebagai berikut:

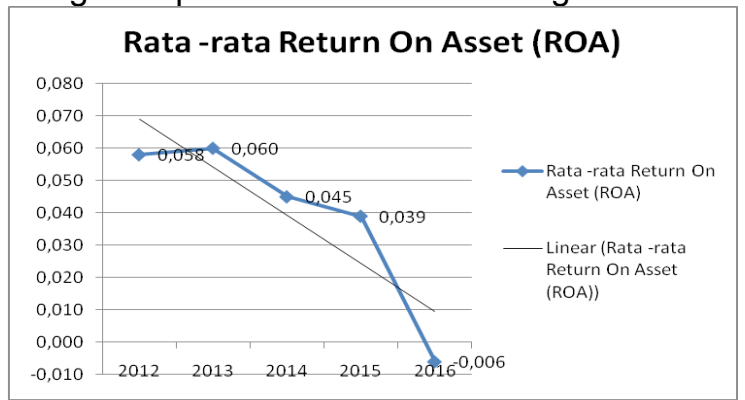

Sumber: Data Diolah (www.idx.co.id)

$$
\text { Gambar } 2
$$

Grafik ROA pada Perusahaan Sub Sektor Konstruksi dan Bangunan

$$
\text { Periode 2012-2016 }
$$

Berdasarkan Tabel 3 dan Gambar 2, perkembangan ROA pada Perusahaan Sub Sektor Konstruksi dan Bangunan 2012-2016 berfluktuasi dan cenderung menurun. Nilai rata-rata ROA pada Perusahaan Sub Sektor Konstruksi dan Bangunan yang terdaftar di Bursa Efek Indonesia periode 2012-2016 adalah sebesar 0,039. ROA maksimum perusahaan adalah sebesar 0,152. pada tahun 
2012 disebabkan aset perusahaan telah dikelola secara efisien.. Sementara nilai minimum ROA perusahaan sebesar $-0,249$, berada pada tahun 2016 .

3) Gambaran Nilai Perusahaan pada Perusahaan Sub Sektor Konstruksi dan Bangunan periode 2012-2016

Rata-rata Market to Book Ratio (MBR) Perusahaan Sub Sektor Konstruksi dan Bangunan sebagai berikut :

Tabel 4

MBR Perusahaan Sub Sektor Konstruksi dan Bangunan periode 2012-2016

\begin{tabular}{|c|c|c|c|c|c|c|c|}
\hline \multirow[b]{2}{*}{ No } & \multirow[b]{2}{*}{ Emiten } & \multicolumn{5}{|c|}{ Market To Book Ratio } & \multirow{2}{*}{$\begin{array}{c}\text { Rata-rata } \\
\text { (kali) }\end{array}$} \\
\hline & & $\begin{array}{l}2012 \\
\text { (kali) }\end{array}$ & $\begin{array}{l}2013 \\
\text { (kali) }\end{array}$ & $\begin{array}{l}2014 \\
\text { (kali) }\end{array}$ & $\begin{array}{l}2015 \\
\text { (kali) }\end{array}$ & $\begin{array}{l}2016 \\
\text { (kali) }\end{array}$ & \\
\hline 1 & $\mathrm{ADHI}$ & 2,290 & 1,499 & 3,049 & 1,479 & 1,363 & 1,936 \\
\hline 2 & DGIK & 0,791 & 0,784 & 0,899 & 0,435 & 0,402 & 0,662 \\
\hline 3 & PTPP & 2,427 & 2,832 & 7,246 & 4,282 & 1,883 & 3,734 \\
\hline 4 & SSIA & 3,176 & 1,136 & 1,901 & 1,157 & 0,701 & 1,614 \\
\hline 5 & TOTL & 4,658 & 2,264 & 4,789 & 2,471 & 2,819 & 3,400 \\
\hline 6 & WIKA & 3,511 & 3,290 & 5,672 & 3,710 & 1,278 & 3,492 \\
\hline 7 & WSKT & 2,048 & 1,086 & 4,903 & 2,374 & 3,127 & 2,708 \\
\hline \multicolumn{2}{|c|}{ Rata-rata Akhir } & 2,700 & 1,841 & 4,066 & 2,273 & 1,654 & 2,507 \\
\hline \multicolumn{7}{|c|}{ Rata-rata Keseluruhan } & 2,507 \\
\hline \multicolumn{7}{|c|}{ Nilai MBR Maksimum } & 7,246 \\
\hline \multicolumn{7}{|c|}{ Nilai MBR Minimum } & 0,402 \\
\hline
\end{tabular}

Sumber: www.idx.co.id (Data diolah)

Berdasarkan Tabel 4 di atas, maka disajikan grafik MBR periode 2012-2016 sebagai berikut:

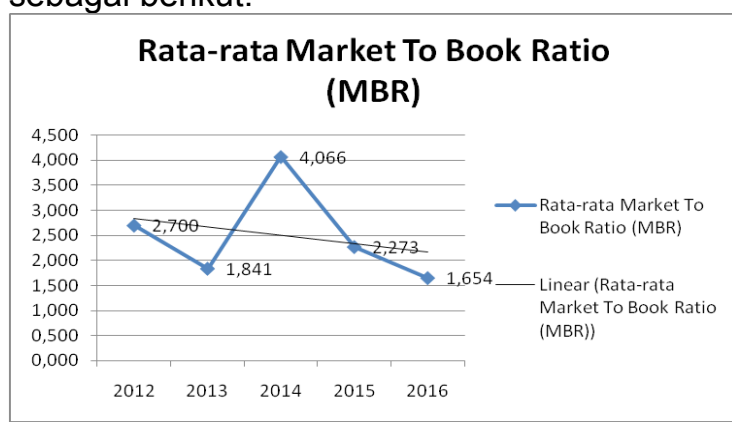

Sumber: Data Diolah (www.idx.co.id)

$$
\text { Gambar } 3
$$

Grafik MBR Perusahaan Sub Sektor Konstruksi dan Bangunan Periode 2012-2016

Berdasarkan Tabel 4 dan Gambar 3 perkembangan MBR Perusahaan Sub Sektor Konstruksi dan Bangunan periode 2012-2016 berfluktuasi dan cenderung menurun. Nilai rata-rata MBR sebesar 2,507. Nilai minimum MBR sebesar 0,402 kali terdapat pada tahun 2016 disebabkan oleh harga pasar saham pada tahun 2016 menurun dibandingkan tahun sebelumnya.

Sedangkan nilai maksimum market to book ratio adalah sebesar 7,246 kali pada tahun 2014. Setiap tahun harga pasar per saham perusahaan meningkat dalam arti perusahaan mampu meningkatkan kinerja perusahaan yang baik, ini akan meningkatkan permintaan saham perusahaan yang diikuti dengan kenaikan harga sahamnya. Nilai perusahaan akan tinggi jika harga saham mengikuti angka yang tinggi juga.

b. Analisis Deskrisptif Kuantitatif

1) Regresi Linier Berganda

Pengujian analisis regresi berganda dengan hasil yang terlihat pada Tabel 5 . Tabel 5

Hasil Analisis Regresi Linier Berganda

\begin{tabular}{|c|r|r|r|}
\hline Model & \multicolumn{2}{|c|}{$\begin{array}{c}\text { Unstandardized } \\
\text { Coefficients }\end{array}$} & \multicolumn{2}{|c|}{$\begin{array}{c}\text { Standardized } \\
\text { Coefficients }\end{array}$} \\
\cline { 2 - 5 } & \multicolumn{1}{|c|}{ B } & $\begin{array}{c}\text { Std. } \\
\text { Error }\end{array}$ & \multicolumn{2}{|c|}{ Beta } \\
\hline \multirow{2}{*}{1 (Constant) } & 8,781 & 1,512 & \multicolumn{2}{|c}{} \\
X1 & $-4,778$ & 1,082 &,- 627 \\
X2 & 13,343 & 3,866 &, 490 \\
\hline
\end{tabular}

Sumber: Hasil Pengolahan Data , 2017

Berdasarkan Tabel 5, model persamaan regresi yang diperoleh adalah sebagai berikut:

$$
\hat{Y}=8,781-4,778 X_{1}+13,343 X_{2}
$$

dapat diartikan likuiditas berpengaruh negatif sementara profitabilitas berpengaruh positif terhadap nilai perusahaan pada Perusahaan Sub Sektor Konstruksi dan bangunan yang Terdaftar di Bursa Efek Indonesia untuk periode 2012-2016.

\section{2) Koefisien Korelasi dan Determinasi}

Koefisien korelasi dan determinasi pada Tabel 6 sebagai berikut:

$$
\text { Tabel } 6
$$

Koefisien Korelasi dan Koefisien Determinasi

\begin{tabular}{|l|c|r|r|r|}
\hline Model & $\mathrm{R}$ & $\begin{array}{c}\mathrm{R} \\
\text { Square }\end{array}$ & $\begin{array}{c}\text { Adjusted } \mathrm{R} \\
\text { Square }\end{array}$ & $\begin{array}{c}\text { Std. Error of the } \\
\text { Estimate }\end{array}$ \\
\hline 1 &, $654^{\mathrm{a}}$ &, 427 &, 392 & 1,253289 \\
\hline
\end{tabular}

a. Predictors: (Constant), X2, X1

Sumber :Hasil Pengolahan, 2017

Berdasarkan Tabel 6 nilai $r$ adalah 0,654 berarti hubungan antara likuiditas dan profitabilitas terhadap nilai perusahaan pada Perusahaan Sub Sektor Konstruksi dan Bangunan adalah kuat. Sementara koefisien determinasi (R Square) adalah 0,427 berarti bahwa variabel nilai prusahaan dijelaskan oleh likuiditas dan profitabilitas sebesar $42,7 \%$ dan sisanya sebesar 57,3\%, dijelaskan oleh variabel lain yang tidak dijelaskan dalam penelitian ini, seperti solvabilitas, cash ratio, volume perdagangan dan profit margin.

3) Uji Hipotesis

a) Uji Simultan (Uji F)

Hasil uji $\mathrm{F}$ penelitian ini pada Tabel 7.

Tabel 7

Hasil Uji F

\begin{tabular}{|l|r|r|r|c|c|}
\hline Model & $\begin{array}{c}\text { Sum of } \\
\text { Squares }\end{array}$ & Df & $\begin{array}{c}\text { Mean } \\
\text { Square }\end{array}$ & F & Sig. \\
\hline $1 \quad$ Regression & 37,532 & 2 & 18,766 & 11,947 &, $000^{\mathrm{b}}$ \\
\hline
\end{tabular}




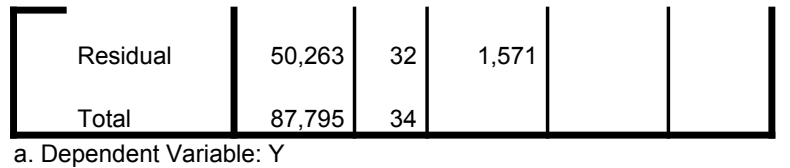

dent Variable: $Y$

b. Predictors: (Constant), X2, X1

Sumber : Hasil Pengolahan Data, 2017

Berdasarkan Tabel 7, hasil uji $F$ menunjukkan $F_{\text {hitung }}>F_{\text {tabel }}(11,947>3,29)$ maka $\mathrm{H}_{0}$ ditolak, berarti antara likuiditas dan profitabilitas berpengaruh signifikan terhadap nilai perusahaan pada Perusahaan Sub Sektor Konstruksi dan Bangunan yang terdaftar di Bursa Efek Indonesia.

b) Uji Parsial (Uji t)

Hasil uji t dalam penelitian ini dapat dilihat pada Tabel 8.

Tabel 8

Hasil Uji t

\begin{tabular}{|c|c|c|c|}
\hline \multicolumn{2}{|c|}{ Model } & $\mathrm{T}$ & Sig. \\
\hline & (Constant) & 5,810 & ,000 \\
\hline 1 & $\mathrm{X} 1$ & $-4,417$ & ,000 \\
\hline & $\mathrm{X} 2$ & 3,451 & ,002 \\
\hline
\end{tabular}

Dependent Variable: $Y$

Sumber : Hasil Pengolahan Data, 2017

Berdasarkan Tabel 8 untuk variabel likuiditas $\left(x_{1}\right)$, nilai $t_{\text {hitung }}<t_{\text {tabel }}(-4,417<$ 2,03693 ) atau tingkat signifikan 0,000 $<0,05$ maka $\mathrm{H}_{0}$ ditolak. Artinya, likuiditas berpengaruh tidak signifikan terhadap nilai perusahaan pada Perusahaan Sub Sektor Konstruksi dan Bangunan yang Terdaftar di BEI.

Untuk variabel profitabilitas $\left(x_{2}\right) t_{\text {hitung }}>t_{\text {tabel }}$ $(3,451>2,03693)$ atau tingkat signifikansi $0,002<0,05$ maka $\mathrm{H}_{0}$ ditolak. Artinya, pofitabilitas berpengaruh signifikan terhadap nilai perusahaan pada Perusahaan Sub Sektor Konstruksi dan Bangunan yang Terdaftar di $\mathrm{BEI}$

\section{Evaluasi}

a. Evaluasi Likuiditas pada Perusahaan Sub Sektor Konstruksi dan Bangunan yang Terdaftar di BEI Periode 2012-2016

Berdasarkan hasil penelitian, perusahaan sebaiknya meningkatkan likuiditasnya dengan menekan persentase kenaikan hutang jangka pendek. Perusahaan juga sebaiknya meningkatkan aset lancarnya supaya perusahaan mampu menutupi hutang jangka pendek yang telah jatuh tempo sehingga investor tertarik untuk berinvestasi didalam perusahaan hal ini dapat meningkatkan nilai perusahaan.

b. Evaluasi Profitabilitas pada Perusahaan Sub Sektor Konstruksi dan Bangunan yang Terdaftar di BEI Periode 2012-2016
Berdasarkan hasil penelitian, sebaiknya perusahaan meningkatkan ROA dengan cara meningkatkan penjualan dan mengefisiensikan biaya usaha, guna meningkatkan laba perusahaan dengan tingginya laba perusahaan maka investor akan tertarik untuk menginvestasikan dananya. Hal ini dapat meningkatkan nilai perusahaan.

c. Evaluasi Nilai Perusahaan pada Perusahaan Sub Sektor Konstruksi dan Bangunan yang Terdaftar di BEI Periode 2012-2016

Berdasarkan hasil penelitian, perusahaan sebaiknya perusahaan meningkatkan harga pasar per saham dengan cara meningkatkan laba perusahaan.

d. Evaluasi Likuiditas Terhadap Nilai Perusahaan pada Perusahaan Sub Sektor Konstruksi dan Bangunan yang Terdaftar di BEI Periode 2012-2016

Hasil regresi diketahui likuiditas memiliki pengaruh negatif terhadap nilai perusahaan.

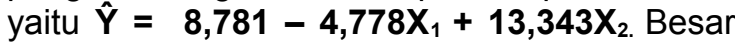
pengaruh yang dimaksud adalah $-4,778$ yang berarti setiap kenaikan likuiditas sebesar 1 satuan akan diikuti penurunan nilai perusahaan sebesar 4,778 dan sebaliknya.

Hasil tersebut sesuai dengan pendapat Riyanto (2009:25), bahwa likuiditas berbanding terbalik dengan profitabilitas. Likuiditas yang baik adalah likuiditas yang dapat meningkatkan laba dan profitabilitas perusahaan. Sehingga laba yang meningkat dapat memberikan sinyal kepada para investor untuk memiliki saham perusahaan, yang pada akhirnya akan meningkatkan harga saham. Harga saham yang meningkat menunjukkan nilai perusahaan meningkat..

e. Evaluasi Profitabilitas Terhadap Nilai Perusahaan pada Perusahaan Sub Sektor Konstruksi dan Bangunan yang Terdaftar di BEI Periode 2012-2016

Berdasarkan hasil regresi profitabilitas berpengaruh positif terhadap nilai perusahaan. Besar pengaruh yang dimaksud adalah 13,343 yang berarti bahwa setiap kenaikan profitabilitas sebesar 1 satuan akan diikuti kenaikan nilai perusahaan sebesar 13,343 dan sebaliknya.

Hasil analisis regresi tersebut sesuai dengan pendapat Kasmir (2012:196), dengan memperoleh laba yang maksimal maka nilai perusahaan juga meningkat atau semakin tinggi rasio profitabilitas yang dihasilkan, maka akan menarik minat para investor dalam menginvestasikan dananya pada perusahaan. Sehingga harga saham juga akan meningkat.

\section{KESIMPULAN DAN SARAN}


1. Kesimpulan

a. Nilai rata-rata likuiditas menggunakan Current Ratio (CR) pada Perusahaan Sub Sektor Konstruksi dan Bangunan yang Terdaftar di Bursa Efek Indonesia tahun 2012-2016 sebesar 1,425 kali dengan nilai maksimum dan minimum adalah 2,006 dan 1,095 kali.

b. Nilai rata-rata profitabilitas menggunakan Return On Assets (ROA) pada Perusahaan Sub Sektor Konstruksi dan Bangunan yang terdaftar di Bursa Efek Indonesia tahun 2012-2016 adalah sebesar 0,039 kali dengan nilai maksimum dan minimum adalah 0,152 dan $-0,249$ kali.

c. Nilai rata-rata nilai perusahaan menggunakan Market To Book Ratio (MBR) pada Perusahaan Sub Sektor Konstruksi dan Bangunan yang terdaftar di Bursa Efek Indonesia tahun 2012-2016 adalah sebesar 2,507 kali dengan nilai maksimum serta minimum adalah 7,246 dan 0,402 .

d. Hasil regresi diperoleh persamaan $\hat{Y}=$ $8,871-4,778 X_{1}+13,343 X_{2}$. bahwa likuiditas berpengaruh negatif sementara profitabilitas berpengaruh positif terhadap nilai perusahaan pada Perusahaan Sub Sektor Konstruksi dan bangunan yang Terdaftar di Bursa Efek Indonesia periode 2012-2016.

e. Koefisien korelasi sebesar 0,654 bahwa hubungan antara likuiditas dan profitabilitas dengan nilai perusahaan memiliki hubungan yang kuat. Koefisien determinasi adalah 0,427 yang berarti Market To Book Ratio dijelaskan oleh Current Ratio (CR) dan Return On Assets (ROA) sebesar $42,7 \%$, sisanya sebesar $57,3 \%$ dijelaskan oleh faktor lain, seperti solvabilitas, cash ratio, volume perdagangan dan profit margin.

f. Hasil uji $\mathrm{F}$ dengan $\mathrm{F}_{\text {hitung }}>\mathrm{F}_{\text {tabel }}(11,947>$ $3,29)$ maka $\mathrm{H}_{0}$ ditolak, berarti likuiditas dan profitabilitas berpengaruh signifikan terhadap nilai perusahaan pada Perusahaan Sub Sektor Konstruksi dan Bangunan yang terdaftar di Bursa Efek Indonesia Periode 2012-2016.

g. Dari hasil uji t diperoleh bahwa nilai:

1) Untuk variabel likuiditas $\left(x_{1}\right) t_{\text {nitung }}<t_{\text {tabel }}$ $(4,417>2,03693)$ atau tingkat signifikan $0,000<0,05$ maka $\mathrm{H}_{0}$ ditolak bahwa likuiditas berpengaruh signifikan terhadap nilai perusahaan pada Perusahaan Sub Sektor Konstruksi dan Bangunan yang terdaftar di Bursa Efek Indonesia Periode 2012-2016.

2) Untuk variabel profitabilitas $\left(x_{2}\right) t_{\text {hitung }}>t_{\text {tabel }}$ $(3,451>2,03693)$ dengan tingkat signifikansi $0,002<0,05$ maka $\mathrm{H}_{0}$ ditolak artinya profitabilitas berpengaruh signifikan terhadap nilai perusahaan pada
Perusahaan Sub Sektor Konstruksi dan Bangunan yang terdaftar di Bursa Efek Indonesia Periode 2012-2016.

2. Saran

a. Sebaiknya perusahaan memperhatikan likuiditas perusahaan, dengan cara menggunakan aset lancar secara efisien. Misalnya dengan melakukan penjualan kredit, menurunkan hutang jangka pendek dan meningkatkan pembayaran dividen..

b. Sebaiknya perusahaan meningkatkan pengelolaan aset dalam menghasilkan laba. Ditingkatkan dengan cara memperhatikan marjin laba, menekan biaya-biaya yang ada di perusahaan seperti biaya usaha, biaya pemeliharaan mesin dan biaya lain-lain.

c. Sebaiknya perusahaan meningkatkan harga sahamnya dengan cara meningkatkan pembagian dividen serta meningkatkan tingkat resiko kerugian dan pengembalian saham.

\section{E. DAFTAR PUSTAKA}

Astuti, Dewi. 2004. Manajemen Keuangan Perusahaan. Jakarta: Ghalia Indonesia

Brigham, Eugene F. dan Joel F.Houston. 2010. Dasar-dasar Manajemen Keuangan, Edisi 11. Jakarta : Salemba Empat.

Harahap, Sofyan Syafri. 2011. Analisis Kritis Atas Laporan Keuangan. Jakarta : PT Raja Grafindo Persada.

Horne, James C. Van dan John M. Wachowiccz, Jr. 2012. Prinsip-prinsip Manajemen Keuangan, Edisi Ketiga belas, Jilid Satu. Jakarta: Salemba Empat.

Kasmir. 2010. Analisis Laporan Keuangan, Edisi Pertama Cetakan Kedua. Jakarta: Prenada Media Grup.

Keown, et. al. 2004. Manjemen Kuengan: Prinsip-prinsip Dasar dan Aplikasi, Edisi Kesembilan, Jilid 1. Jakarta: PT Indeks Kelompok Gramedia.

Munawir, S. 2004. Analisa Laporan Keuangan, Edisi Keempat. Yogyakarta : Liberty.

Riyanto, Bambang. 2009. Dasar-dasar Pembelanjaan Perusahaan, Edisi Keempat. Yogyakarta : BPFE Yogyakarta. 
